\title{
PAPER ELECTROPHORESIS AS A QUANTITATIVE METHOD: MEASUREMENT OF ALPHA AND BETA LIPOPROTEIN CHOLESTEROL
}

\author{
By. THOMAS A. LANGAN, E. L. DURRUM,1 and WILlIAM P. JENCKS ${ }^{2}$ \\ (From the Department of Pharmacology, Army Medical Service Graduate School, Walter \\ Reed Army Medical Center, Washington, D. C.)
}

(Submitted for publication March 21, 1955; accepted May 11, 1955)

The development of methods for the separation and measurement of serum lipoproteins by ultracentrifugal flotation, fractional precipitation and zone electrophoresis has made possible studies of the metabolism and pathological significance of several lipoprotein fractions. Except for early studies by Lindgren, Elliott, Gofman, Jones, Lyon, and Strisower on the relationship of beta lipoprotein subfractions of certain flotation rates to atherosclerosis $(1,2)$ most of these studies have been concerned with alpha and beta lipoproteins, as defined by density in the ultracentrifugal techniques (3-5), by solubility in the chemical fractionation techniques (6) and by mobility in electrophoretic separation. Using a protein fractionation procedure developed by Cohn and his group (7), Barr, Russ, and Eder $(8,9)$ found that in 33 atherosclerotic individuals an average of only 13.6 per cent of the total serum cholesterol was associated with the alpha lipoprotein fraction as compared to 27.8 per cent in 85 normals.

In an attempt to avoid the complex equipment and technique and the large amount of serum required for the ultracentrifugal and chemical techniques, several workers have taken advantage of the ease of separation of alpha and beta lipoproteins by electrophoresis in anti-convection media such as starch and filter paper. The separated lipoproteins were then measured either by staining techniques, which are dependent on the solubility of lipid dyes in certain serum lipids (10-14 and others), or by the more specific method of elution and chemical determination of the cholesterol in the alpha and beta lipoprotein fractions (15-21). Thus Nikkilä (15), using $0.24 \mathrm{ml}$. of

\footnotetext{
1 Present address : Department of Pharmacology, Stanford University Medical School, Clay \& Webster Sts., San Francisco 15, California.

2 Present address: Biochemical Research Laboratory, Massachusetts General Hospital, Fruit St., Boston, Mass.
}

serum separated on three sheets of $11 \times 30 \mathrm{~cm}$. paper has shown a decrease in alpha lipoprotein cholesterol in atherosclerotic patients, and Kunkel and Slater (22) have made use of starch blocks as supporting media in order to avoid the "tailing" of lipoproteins encountered with filter paper. The techniques of cholesterol measurement used in these studies have the disadvantages of being timeconsuming and of requiring larger amounts of serum than can be adequately separated on a single paper strip of reasonable size.

Zlatkis, Zak, and Boyle have recently described a method for the determination of the total cholesterol of whole serum without extraction, precipitation or hydrolysis, which is several times more sensitive than the Schoenheimer-Sperry technique and which gives equal color with cholesterol and cholesterol esters (23). Use of this method on whole serum has been criticized by Best, Van Loon, Wathem, and Seger (24) who found that it gave high values compared to the Schoenheimer-Sperry method, and by Fürst and Lange (25) who found variations in color with changes in temperature or amounts of reagent.

A method is described here for the determination of alpha and beta lipoprotein cholesterol on eluates from $0.02 \mathrm{ml}$. of electrophoretically separated serum. Cholesterol is determined by a modification of the Zlatkis, Zak, and Boyle procedure which gives satisfactory agreement with the Schoenheimer-Sperry technique. The small amount of serum required allows a clear cut separation of the alpha and beta fractions in a short migration distance without overloading of the paper and without measurable error due to "tailing." The method is suited for large scale clinical studies with regard to time, technique and apparatus involved and meets clinical standards of reproducibility and quantitative recovery. 


\section{MATERIALS AND METHODS}

\section{Reagents}

1. Barbital buffer, $\mathrm{pH} 8.6,0.05 \mu .1 .84 \mathrm{~g}$. of diethylbarbituric acid and $10.3 \mathrm{~g}$. of sodium barbital were dissolved in one liter of distilled water.

2. Sudan black staining solution was prepared according to Swahn (10). One liter of 60 per cent ethanol was saturated with $1 \mathrm{~g}$. of Sudan black B (National Aniline Division, Allied Chemical and Dye Corporation) by bringing to the boiling point. The solution was cooled to room temperature, filtered, and stored in a closed container.

3. Chloroform-methanol solvent: Two volumes of redistilled chloroform were mixed with one volume of redistilled methanol just prior to use. These solvents were freshly distilled no more than two weeks before use.

4. Standard cholesterol solution: One hundred $\mathrm{mg}$. of recrystallized cholesterol was dissolved in glacial acetic acid and made up to $100 \mathrm{ml}$. at $25^{\circ} \mathrm{C}$. This solution was stored frozen in the refrigerator and warmed to $24^{\circ}$ to $26^{\circ} \mathrm{C}$. before samples were withdrawn. Under these conditions no measurable deterioration of the standard solution was found over a period of four months.

5. Glacial acetic acid: Except as otherwise specified, reagent grade glacial acetic acid (Fisher Chemical Co.) was used. Acetic acid was tested for the presence of glyoxylic acid which would give color with tryptophane by a modification of the method of Brice (26). Five hundredths $\mathrm{ml}$. of $100 \mathrm{mg}$. per cent aqueous tryptophane was added to $0.95 \mathrm{ml}$. of the acetic acid to be tested. A volume of $0.65 \mathrm{ml}$. of sulfuric acid was then added, and the mixture was heated for 20 minutes at $56^{\circ} \mathrm{C}$. A pink color indicates the presence of glyoxylic acid. Acetic acid which was used for cholesterol determinations gave a faint or negative reaction with this test.

6. Ferric chloride-sulfuric acid cholesterol reagent (23) : One g. of reagent grade $\mathrm{FeCl}_{3} \cdot 6 \mathrm{H}_{2} \mathrm{O}$ (Coleman \& Bell Co.) was dissolved in glacial acetic acid and made up to $10.0 \mathrm{ml}$. in a volumetric flask. Five ml. of this solution was diluted to $500 \mathrm{ml}$. with concentrated suliuric acid (Baker and Adamson C.P. reagent). The resulting pale yellow solution was stored in a separatory funnel plugged with a drying tube containing anhydrous calcium sulfate (Drierite) to prevent absorption of moisture from the air. Reagent kept in this way over one month gave the same results as fresh reagent.

\section{Procedure}

1. Elcctrophoresis: Electrophoretic separation was carried out on eight $2.9 \times 30.0 \mathrm{~cm}$. Whatman $3 \mathrm{MM}$ filter paper strips in a cell of the hanging strip type (27). To minimize variations in the final color caused by material in the paper, all strips used in each determination were cut from the same sheet of filter paper and care was taken to keep the strips clean and free from perspiration. After the strips had been wet with buffer and allowed to drain for 15 minutes, $0.02 \mathrm{ml}$. of serum was applied in a streak at the apex of each strip with a micropipette (Microchemical Specialties Co., Berkeley, California), and a potential of 220 volts (14-17 m.a.) was applied for two hours. The strips were then spread flat to avoid shifts in the bands during drying, and dried with a current of air at room temperature. Each serum was run in duplicate along with an additional sample for staining.

2. Staining: Those strips which were to be used to locate the lipoprotein bands were dried horizontally for 10 minutes in an oven at $110^{\circ} \mathrm{C}$., stained for one hour in Sudan black staining solution, rinsed for a few minutes in tap water, blotted, and again dried. One strip could be used for the location of the lipoprotein bands of two different sera by applying two $0.01 \mathrm{ml}$. samples to a strip with a $2 \times 120 \mathrm{~mm}$. slit cut down its center (Figure 1)

3. Elution: The apparatus used for eluting cholesterol from the strips is shown in Figure 2. A thermostatically controlled heating block maintains the solvent in the tubes at a steady boil with the vapors condensing on air cooled stainless steel condensers or "cold finger" condensers constructed from conical centrifuge tubes. $\mathrm{Pa}$ per segments attached to the condensers are exposed to

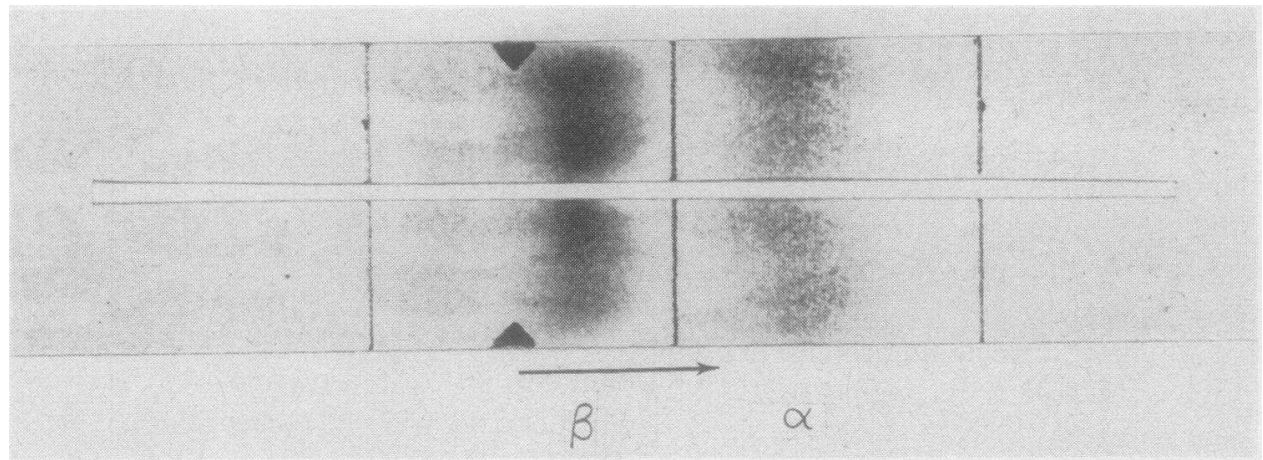

Fig. 1. Slotted Paper Strip Showing Typical Alpha and Beta Lipoprotein Bands of Two Sera Stained with Sudan Black

The lines represent the point for division of the bands on corresponding unstained strips. The carets show the point of serum application. 


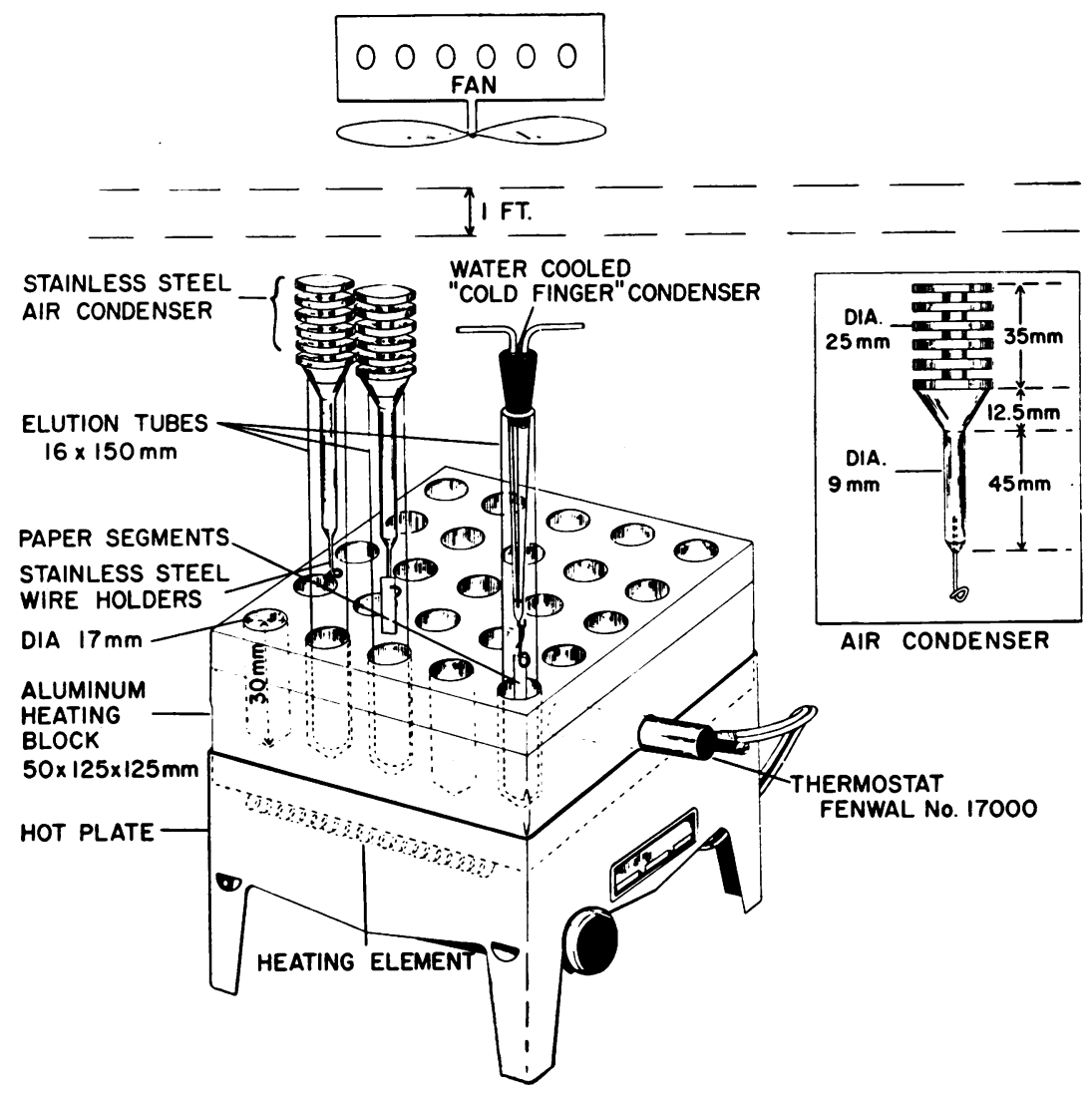

Fig. 2. Apparatus Used for Elution of Serum Cholesterol from Paper STRIPS

a constant flow of fresh solvent, thus accomplishing an elution similar in principle to a Soxhlet extraction. The thermostat on the block is adjusted so as to maintain 4 $\mathrm{ml}$. of water in an elution tube at 72 to $73^{\circ} \mathrm{C}$. This provides for rapid boiling without excessive loss of solvent during the elution. The tops of the elution tubes are ground at a bevel to provide a close fit to the metal condensers.

The lipid patterns on the stained strips were marked off into two $3 \mathrm{~cm}$. segments which best separated the alpha and beta fractions and which together included the entire lipid pattern (Figure 1). Identical segments were then marked off on the unstained strips by aligning them with the corresponding stained pattern at the point of serum application. These unstained segments were cut out, folded with tweezers in one direction to four or five thicknesses and forced into the wire loops on the condensers. A $3 \mathrm{~cm}$. segment cut from the cathode side of a strip was used as a blank. Four ml. of chloroformmethanol solvent was added to each elution tube along with an alumina boiling chip, and the tubes were placed in the heating block and allowed to come to a boil.. The condensers were then placed in the tubes and adjusted so that the shafts did not touch the walls of the elution tubes, thus preventing the refluxing solvent from being drained off the condensers onto the walls of the tubes without passing through the paper segments. The segments were eluted for two hours and the tubes were allowed to stand overnight.

4. Detcrmination of cholesterol: The cholesterol in the eluate was determined by a modification of the method of Zlatkis, Zak, and Boyle (23). After the condensers were removed from the tubes and a fresh boiling stone added, the solvent was again brought to a boil on the block. A cardboard cover with holes for the openings of the tubes was placed over the apparatus to help the evaporation by warming the tubes and preventing condensation of vapor on their walls. The cover was constructed so as to enclose the entire space above the heating block up to the top of the tubes. After the solvent had been allowed to evaporate for one hour the cover was removed, $1.00 \mathrm{ml}$. of glacial acetic acid was added to the dry residue in each tube, and the tubes were replaced in the heated block for 15 minutes to insure solution of the residue. At this point two standards were prepared by pipetting $0.02 \mathrm{ml}$. of the standard cholesterol solution into each of two elution tubes and adding $0.98 \mathrm{ml}$. of glacial acetic acid. A volume of 1.00 $\mathrm{ml}$. of acetic acid was added to an elution tube for use as a reagent blank. After the tubes had cooled, $0.65 \mathrm{ml}$. 
of ferric chloride-sulfuric acid cholesterol reagent was added to each tube from a $10 \mathrm{ml}$. burette, allowing it to run slowly down the wall of the tube from a point about $3 \mathrm{~cm}$. above the level of the acetic acid so as to form a layer under the acetic acid. Immediately after adding the reagent each tube was struck sharply with the fingers to mix the reagents and placed in a $56^{\circ} \pm 1^{\circ} \mathrm{C}$. water bath for 20 (17 to 23) minutes. Samples containing cholesterol developed a brownish purple color, while elution blanks were pale yellow. The solutions were allowed to cool to room temperature, transferred to matched $10 \times$ $75 \mathrm{~mm}$. round cuvettes, centrifuged briefly to remove bubbles, and read within one hour in a Coleman Junior Spectrophotometer at $560 \mathrm{~m} \mu$. In transferring the viscous samples to the cuvettes, the elution tubes were allowed to drain while supported in an inverted position by $1 \times 110$ $\mathrm{mm}$. glass rods placed in the cuvettes. The optical density developed in the standard tubes showed a range of variation of 10 per cent over several months.

For the determination of eluted cholesterol by the Sperry and Webb modification of the SchoenheimerSperry procedure (28) it was necessary to combine eluates from two strips. The evaporation was carried out until about $1 \mathrm{ml}$. of solvent remained in each tube, and duplicate eluates were then combined, rinsing three times with $1 \mathrm{ml}$., $0.5 \mathrm{ml}$., and $0.5 \mathrm{ml}$. of chloroform-methanol. The combined eluates were evaporated to dryness, and the residue extracted three times with $1 \mathrm{ml}$., $0.75 \mathrm{ml}$., and $0.75 \mathrm{ml}$. of ethanol-ether $(3: 1)$, transferring the extracts to a $15 \mathrm{ml}$. conical centrifuge tube. Hydrolysis, digitonin precipitation and color development were then carried out in the usual manner.

\section{RESULTS}

\section{Color development and elution}

Determination of the total cholesterol of whole serum with the ferric chloride-sulfuric acid reagent without extraction, hydrolysis or precipitation (23) has in our hands given results which do not consistently agree with those obtained with the Schoenheimer-Sperry method, in confirmation of the report by Best, Van Loon, Wathem, and Seger (24). Use of acetic acid which had been refluxed over chromic acid and redistilled twice (29) did not improve the results.

However, when the reaction was carried out on chloroform-methanol extracts of serum which had been electrophoretically separated on paper strips, and the temperature during color development was controlled by use of a $56^{\circ}$ water bath, satisfactory results were obtained. ${ }^{3}$

3 After this work was completed, Zak, and his coworkers published a method for the determination of total serum cholesterol with the ferric chloride-sulfuric
TABLE I

Color development with whole serum and eluted serum using acetic acid of varying degrees of purity *

\begin{tabular}{cccccc}
\hline \hline & \multicolumn{4}{c}{ Net O.D. at $560 \mathrm{~m} \mu$} \\
\cline { 3 - 6 } & & \multicolumn{4}{c}{ Acetic acid } \\
\cline { 3 - 6 } & & $\begin{array}{c}\text { Puri- } \\
\text { fied }\end{array}$ & Reagent & U.S.P. \\
\hline $\mathrm{H}_{2} \mathrm{SO}_{4}-\mathrm{FeCl}_{3}$ & Whole serum & .379 & .407 & .433 \\
$\mathrm{Reagent}$ & Eluted serum & .366 & .375 & .360 \\
$\mathrm{H}_{2} \mathrm{SO}_{4}$ only & Whole serum & .097 & .126 & .144 \\
& Eluted serum & .068 & .055 & .062 \\
Glyoxylic acid reaction & 0 & + & +++
\end{tabular}

* Purified acetic acid was refluxed over chromic acid and redistilled. Eluted samples are from serum streaked and dried on filter paper. Color development was carried out as described in the text.

Table I shows the influence of impurities in the acetic acid on the amount of color developed in the determination of cholesterol on whole serum and on chloroform-methanol extracts of serum streaks dried on paper. It may be seen that with lots of acetic acid giving increasingly strong glyoxylic acid reactions there is an increase in the amount of color developed with whole serum, but

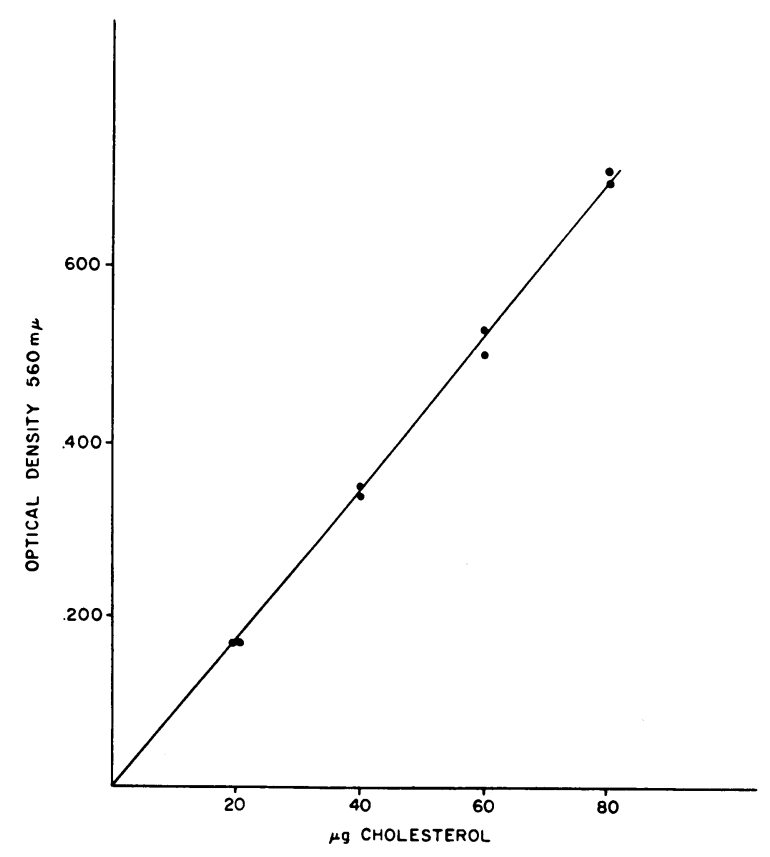

Fig. 3. Standard Curve for Pure Cholesterol

acid reagent on alcohol-acetone extracts of sera which shows satisfactory agreement with the Kingsley-Schaffert procedure (30). 


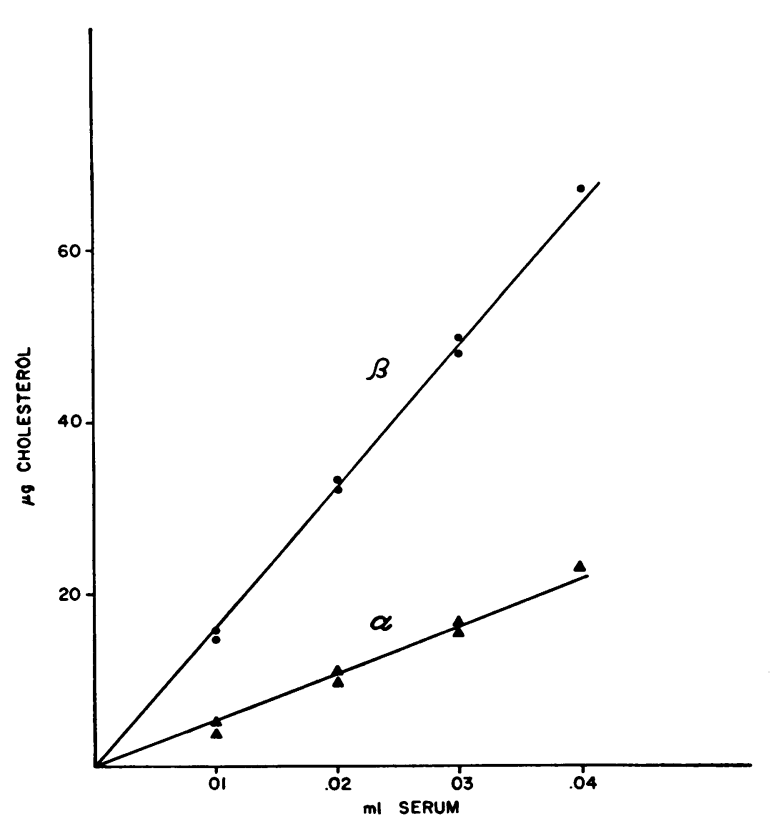

Fig. 4. Determination of Cholesterol in Eluates from Alpha and Beta Lipoprotein Fractions of InCreasing Amounts of Serum

that no such increase occurs with eluates of the same serum. If ferric chloride is omitted so that the reaction is carried out under the conditions of the glyoxylic acid-tryptophane reaction, the same results are obtained. The small amount of color developed in all samples without ferric chloride is probably due to the reaction of small amounts of oxidizing substances present in the reaction mixture with cholesterol.

Figure 3 shows that the color developed with increasing amounts of pure cholesterol increases linearly up to an optical density of at least 0.700 when measured in the Coleman Junior Spectrophotometer after 20 minutes color development in the $56^{\circ}$ bath. After this incubation the color is stable for at least one hour at room temperature or for 20 minutes at $56^{\circ}$.

Figure 4 shows that a linear response is also obtained with increasing amounts of serum carried through the complete process of electrophoretic separation, elution, and color development. The total cholesterol of this serum as determined by the Schoenheimer-Sperry technique was 212 mg. per cent, as compared to $216 \mathrm{mg}$. per cent obtained by adding the alpha and beta values shown. Thus the efficiency of separation and elution of the serum is not dependent on the quantity of ma-
TABLE II

Recovery of added cholesterol

\begin{tabular}{|c|c|c|c|c|c|}
\hline Serum & Fraction & $\begin{array}{c}\begin{array}{c}\text { Serum } \\
\text { cholesterol } \\
\boldsymbol{\mu g} .\end{array} \\
\end{array}$ & $\begin{array}{c}\text { Found } \\
\text { after } \\
\text { addition } \\
\text { of } 20 \mu \mathrm{g} . \\
\text { cholesterol }\end{array}$ & $\begin{array}{c}\text { Recovery } \\
\text { of added } \\
\text { cholesterol } \\
\boldsymbol{\mu g} .\end{array}$ & $\begin{array}{c}\text { Re- } \\
\text { covery } \\
\%\end{array}$ \\
\hline Pool I* & $\begin{array}{l}\text { Alpha } \\
\text { Beta }\end{array}$ & $\begin{array}{r}8.9 \\
31.5\end{array}$ & $\begin{array}{l}29.6 \\
50.2\end{array}$ & $\begin{array}{l}20.7 \\
18.7\end{array}$ & $\begin{array}{r}104 \\
94\end{array}$ \\
\hline 1149 & $\begin{array}{l}\text { Alpha } \\
\text { Beta }\end{array}$ & $\begin{array}{r}7.1 \\
36.2\end{array}$ & $\begin{array}{l}27.6 \\
57.0\end{array}$ & $\begin{array}{l}20.5 \\
20.8\end{array}$ & $\begin{array}{l}103 \\
104\end{array}$ \\
\hline 1221 & $\begin{array}{l}\text { Alpha } \\
\text { Beta }\end{array}$ & $\begin{array}{l}10.2 \\
23.0\end{array}$ & $\begin{array}{l}31.2 \\
43.5\end{array}$ & $\begin{array}{l}21.0 \\
20.5\end{array}$ & $\begin{array}{l}105 \\
103\end{array}$ \\
\hline 1579 & $\begin{array}{l}\text { Alpha } \\
\text { Beta }\end{array}$ & $\begin{array}{r}8.5 \\
41.4\end{array}$ & $\begin{array}{l}29.3 \\
62.0\end{array}$ & $\begin{array}{l}20.8 \\
20.6\end{array}$ & $\begin{array}{l}104 \\
103\end{array}$ \\
\hline
\end{tabular}

* Pooled serum from 10 blood donors.

terial involved over a range of one-half to two times the amount ordinarily used.

Table II shows the recovery of added cholesterol, which was streaked over alpha and beta fractions of sera which had been previously separated and dried. The quantitative recovery obtained is evidence against the presence in the serum of inhibitors or other impurities affecting the color development due to cholesterol.

A comparison of the results obtained with the complete separation, elution and color development procedure on six different normal and abnormal sera with the results of Schoenheimer-Sperry determinations of total serum cholesterol on the same sera is shown in Table III. The sum of the values obtained for alpha and beta lipoprotein cholesterol agrees with the results of the Schoenheimer-Sperry method within the sum of the er-

TABLE III

Recovery of eluted cholesterol determined by the ferric chloride and Schoenheimer-Sperry methods

\begin{tabular}{|c|c|c|c|c|c|}
\hline Serum & $\begin{array}{l}\text { Schoen- } \\
\text { heimer- } \\
\text { Sperry } \\
\text { serum } \\
\text { cholesterol } \\
\text { mg. } \%\end{array}$ & $\begin{array}{l}\text { Ferric } \\
\text { chloride } \\
\text { eluted } \\
\text { cholesterol } \\
\text { (sum of } \\
\text { alpha } \\
\text { and beta) } \\
\text { mg. \% }\end{array}$ & $\begin{array}{c}\text { Re- } \\
\text { covery } \\
\%\end{array}$ & $\begin{array}{l}\text { Schoen- } \\
\text { heimer- } \\
\text { Sperry } \\
\text { eluted } \\
\text { cholesterol } \\
\text { mg. \% }\end{array}$ & $\begin{array}{c}\text { Re- } \\
\text { covery } \\
\%\end{array}$ \\
\hline $\begin{array}{l}1589 \\
1590 \\
1592 \\
1593 \\
1595 \\
\text { Pool II* }\end{array}$ & $\begin{array}{l}202 \\
331 \\
238 \\
332 \\
328 \\
288\end{array}$ & $\begin{array}{l}192 \\
326 \\
258 \\
337 \\
330 \\
261\end{array}$ & $\begin{array}{r}95 \\
99 \\
110 \\
102 \\
101 \\
91\end{array}$ & $\begin{array}{l}213 \\
322 \\
247 \\
309 \\
306 \\
264\end{array}$ & $\begin{array}{r}106 \\
97 \\
103 \\
96 \\
93 \\
92\end{array}$ \\
\hline $\begin{array}{l}\text { Average } \\
\text { recovery }\end{array}$ & & & 100 & & 98 \\
\hline
\end{tabular}

* Pool of 5 sera. 
TABLE IV

Elution of cholesterol from alpha and beta lipoproteins

\begin{tabular}{lcc}
\hline & \multicolumn{2}{c}{$\mu \mathrm{g}$. Cholesterol recovered } \\
\cline { 2 - 3 } \multicolumn{1}{c}{ Elution period } & Alpha & Beta \\
\hline 0 to $1 \frac{1}{2}$ hrs. & 10.3 & 34.4 \\
$1 \frac{1}{2}$ hrs. to 2 hrs. & $-0.1^{*}$ & $-0.4^{*}$ \\
2 hrs. to 4 hrs. & $-0.2^{*}$ & 0.4 \\
4 hrs. to 19 hrs. & $-0.2^{*}$ & 0.3 \\
\hline
\end{tabular}

Serum: Pool I from 10 blood donors.

Cholesterol applied (Schoenheimer-Sperry method) : $42.4 \mu g$.

Cholesterol recovered (Ferric chloride method, sum of $1 \frac{1}{2} \mathrm{hr}$. alpha and beta values): $44.7 \mu \mathrm{g}$.

* Negative figures represent values lower than the blanks. These differences are no greater than the error of the determination.

rors of the two methods. To insure that the apparently complete recovery was not an artifact due to a combination of incomplete elution and erroneously high values with the ferric chloride procedure, the same sera were electrophoretically separated, the entire lipid containing area was eluted, and the combined eluates from two strips were analyzed for cholesterol by the Schoenheimer-Sperry procedure. The last two columns of Table III show that these values agree satisfactorily with those obtained with the ferric chloride method.

As a further test of the completeness of the twohour elution procedure, the alpha and beta segments of two strips were eluted for a total of nineteen hours, transferring the segments to fresh elution tubes at intervals and determining the cholesterol extracted during each period. As shown in Table IV, no additional cholesterol was recovered after one and one-half hours of elution. The recovery (sum of one and one-half hours alpha and beta values $v s$. Schoenheimer-Sperry total) was 105 per cent.

The blank values obtained by elution of an area of the paper strip containing no protein could be lowered somewhat by extraction of the strip with fat solvents before use. However, since the net values for eluted serum cholesterol were not changed by such a procedure, it was not ordinarily carried out. The buffer salts in the dried paper, which are eluted along with the lipid material, do not give color or affect the color reaction.

\section{Electrophoretic separation}

Separation of the alpha and beta lipoprotein fractions of serum was carried out simultaneously on eight filter paper strips moistened with $\mathrm{pH} 8.6$ barbital buffer in the cell previously described (27). Using $0.02 \mathrm{ml}$. of serum, a clear cut separation of alpha and beta lipoproteins as revealed by Sudan black staining was invariably obtained. Figure 1 shows a typical "marker" strip which was used to locate the lipoprotein bands for each of the sera run in the same cell.

The point used for dividing the alpha and beta fractions was about $2 \mathrm{~mm}$. ahead of the sharply defined front of the beta lipoprotein band; no evidence was obtained by staining for the presence of other lipoprotein fractions in practicably measurable amounts. However, in certain pathological sera, the "beta lipoprotein" band moved ahead of the beta globulins as revealed by protein staining. Since all gradations of mobility between alpha and beta globulin were observed for this lipoprotein fraction in a series of such sera, while the mobility of alpha lipoproteins was remarkably constant, it seemed most reasonable to consider these to be abnormal forms of beta lipoprotein rather than another fraction of alpha lipoprotein. No attempt was made to distinguish between chylomicrons and beta lipoprotein adsorbed at the application point; such a differentiation would presumably be of little importance in any case because of the low cholesterol content of chylomicrons (1).

Under these conditions of electrophoretic separation, the leading edge of the alpha lipoprotein band migrated 3 to $4 \mathrm{~cm}$. from the origin. This relatively short migration distance was selected in order to minimize the possibility of error due to "tailing" of alpha lipoprotein and the high blank values obtained if large amounts of paper are eluted. As mentioned above, "tailing" of beta lipoproteins is of no consequence, since any beta "tail" is eluted with the band itself. The linear recovery of cholesterol obtained with electrophoresis and elution of increasing amounts of serum (Figure 4) rules out the possibility of significant adsorption of the alpha lipoprotein of the kind ordinarily observed, in which a fairly constant amount of material is adsorbed on a given area of paper regardless of the amount applied. The occurrence of an appreciable amount of this type of "tailing" would result in a displacement of the alpha and beta lipoprotein lines so that the latter would intersect the ordinate above zero, and the former below zero, as found with albumin "tail- 


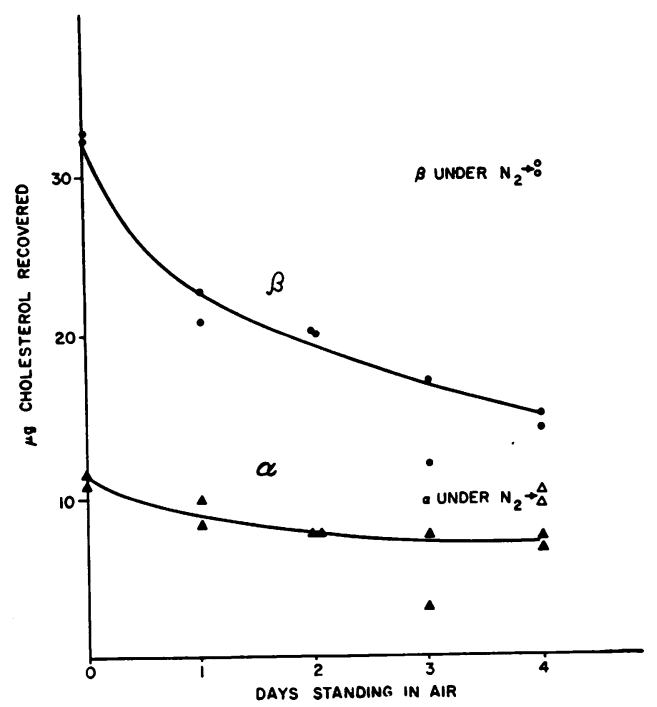

Fig. 5. Decomposition of Alpha and Beta Lipoprotein Cholesterol on Paper Strips Standing in Air AT ROOM TEMPERATURE

ing” (31, 32). It is likely that albumin, passing over the paper surface in front of the alpha lipoprotein, covers up the available adsorptive sites on the paper, thus "laying down a carpet" for the globulin fractions.

\section{Decomposition of cholesterol}

The recovery of cholesterol from a series of identical strips eluted at varying periods of time after electrophoretic separation is shown in Figure 5. It may be seen that after the strips had stood in air at room temperature for four days there was a 55 per cent loss of cholesterol as determined by the ferric chloride procedure. Strips which had been kept under nitrogen for the same period of time showed only a 16 per cent loss, suggesting that oxidation was responsible for the decomposition. In a similar experiment strips which had been allowed to stand for seven days in air showed a 42 per cent loss by the ferric chloride method, and a 27 per cent loss by the Schoenheimer-Sperry procedure. In order to avoid this type of decomposition, the dried strips were eluted within a few hours of the electrophoretic separation. No losses were observed on allowing the eluted cholesterol to stand in solution overnight.

Oxidation of cholesterol under these conditions is not unexpected in view of the results of Bergström and Wintersteiner (33) who observed a rapid oxidation of colloidal cholesterol in water by a stream of air at elevated temperatures and a significant rate of decomposition at $37^{\circ}$.

In view of these observations, it appeared necessary to examine the possibility of losses of cholesterol during the electrophoretic procedure itself. Experiments in which pure cholesterol was applied to strips from a solution of acetic acid, dried, the strips moistened with buffer, and the complete electrophoretic and elution procedure carried out, did show recoveries which were 12 to 15 per cent low. However, numerous experiments on serum, including those reported in Table III, failed to show any evidence of decomposition and no difference in cholesterol recovery was observed if the electrophoretic procedure was carried out at 0 to $1^{\circ} \mathrm{C}$. in an attempt to decrease any oxidation that might be taking place by lowering the temperature. Table II, already referred to, shows that pure cholesterol added to the area of the alpha and beta bands is recovered completely. It appears that decomposition of cholesterol does not readily take place in solution, but is appreciable when exposed to air in the solid or colloidal state. It is possible that serum exerts a specific protective effect because of the presence of antioxidants in serum. It is generally known that while lipoproteins are stable in serum for several weeks at $5^{\circ}$, they undergo rapid oxidation in the absence of serum as shown by increases in electrophoretic mobility and decreases in ultracentrifugal flotation rates $(34,35)$.

As a further check on the method, the ratios of the alpha and beta lipoproteins of three pooled sera were determined by both the Schoenheimer-

TABLE V

Comparison of the Schoenheimer-Sperry and ferric chloride methods in the determination of lipoprotein cholesterol distribution

\begin{tabular}{|c|c|c|}
\hline \multirow[b]{2}{*}{ Serum } & \multicolumn{2}{|c|}{$\begin{array}{l}\% \text { of total cholesterol in alpha } \\
\text { lipoprotein fraction }\end{array}$} \\
\hline & $\begin{array}{l}\text { Schoenheimer- } \\
\text { Sperry } \\
\text { method }\end{array}$ & $\begin{array}{l}\text { Ferric } \\
\text { chloride } \\
\text { method }\end{array}$ \\
\hline Pool III* & $\begin{array}{l}23.4 \\
21.4\end{array}$ & $\begin{array}{l}22.9 \\
21.9\end{array}$ \\
\hline Pool IV* & $\begin{array}{l}20.5 \\
19.4\end{array}$ & $\begin{array}{l}19.7 \\
19.4\end{array}$ \\
\hline Pool V* & $\begin{array}{l}20.4 \\
18.3\end{array}$ & $\begin{array}{l}19.9 \\
18.5\end{array}$ \\
\hline
\end{tabular}

* Pooled serum from 10 blood donors. 
TABLE VI

Reproducibility of lipoprotein cholesterol distribution and total cholesterol in five separate determinations on six normal and abnormal sera

\begin{tabular}{|c|c|c|c|}
\hline Serum & $\begin{array}{l}\text { Experiment } \\
\text { No. }\end{array}$ & $\begin{array}{l}\% \text { Alpha } \\
\text { lipoprotein } \\
\text { cholesterol }\end{array}$ & $\begin{array}{c}\text { Total } \\
\text { cholesterol } \\
\text { (sum of alpha } \\
\text { and beta) } \\
m g . \%\end{array}$ \\
\hline \multirow[t]{2}{*}{1149} & $\begin{array}{l}1 \\
2 \\
3 \\
4 \\
5\end{array}$ & $\begin{array}{l}19.0 \\
18.6 \\
17.8 \\
17.3 \\
19.6\end{array}$ & $\begin{array}{l}240 \\
218 \\
224 \\
230 \\
235\end{array}$ \\
\hline & Average & 18.5 & 229 \\
\hline \multirow[t]{2}{*}{1209} & $\begin{array}{l}1 \\
2 \\
3 \\
4 \\
5\end{array}$ & $\begin{array}{l}16.0 \\
15.7 \\
16.8 \\
16.6 \\
16.7\end{array}$ & $\begin{array}{l}315 \\
303 \\
307 \\
327 \\
322\end{array}$ \\
\hline & Average & 16.4 & 315 \\
\hline \multirow[t]{2}{*}{1221} & $\begin{array}{l}1 \\
2 \\
3 \\
4 \\
5\end{array}$ & $\begin{array}{l}30.4 \\
30.7 \\
31.6 \\
32.5 \\
31.8\end{array}$ & $\begin{array}{l}191 \\
170 \\
175 \\
191 \\
197\end{array}$ \\
\hline & Average & 31.4 & 185 \\
\hline \multirow[t]{2}{*}{1493} & $\begin{array}{l}1 \\
2 \\
3 \\
4 \\
5\end{array}$ & $\begin{array}{l}14.1 \\
13.8 \\
13.6 \\
14.3 \\
15.4\end{array}$ & $\begin{array}{l}336 \\
312 \\
318 \\
334 \\
333\end{array}$ \\
\hline & Average & $\overline{14.2}$ & 327 \\
\hline \multirow[t]{2}{*}{1579} & $\begin{array}{l}1 \\
2 \\
3 \\
4 \\
5\end{array}$ & $\begin{array}{l}17.5 \\
16.9 \\
18.6 \\
16.2 \\
17.9\end{array}$ & $\begin{array}{l}280 \\
252 \\
269 \\
274 \\
283\end{array}$ \\
\hline & Average & 17.4 & 272 \\
\hline \multirow[t]{2}{*}{ Pool I* } & $\begin{array}{l}1 \\
2 \\
3 \\
4 \\
5\end{array}$ & $\begin{array}{l}24.7 \\
22.0 \\
24.4 \\
25.0 \\
26.9\end{array}$ & $\begin{array}{l}228 \\
211 \\
218 \\
222 \\
230\end{array}$ \\
\hline & Average & $\overrightarrow{24.6}$ & $\overline{222}$ \\
\hline
\end{tabular}

* Pooled serum from 10 blood donors.

Sperry and ferric chloride methods. Because of the comparatively low sensitivity of the SchoenheimerSperry method, it was necessary to elute segments from strips on which $0.04 \mathrm{ml}$. of serum had been run, and to combine the eluates from four alpha segments and from two beta segments for the determination of cholesterol in the respective fractions. The results of such an experiment, shown in Table $\mathrm{V}$, indicate that closely comparable values for the distribution of cholesterol between the alpha and beta lipoproteins are obtained by both methods and that no combination of errors in the ferric chloride method is giving rise to incorrect values for alpha and beta lipoprotein cholesterol while giving satisfactory agreement between the two methods for total cholesterol (Table III).

\section{Reproducibility}

The results of a study of the reproducibility of the method under conditions of routine use are shown in Table VI. The complete separation, elution and color development procedure was carried out in duplicate on each of six sera in five separate experiments over a period of nine days. The widest range of variation observed was from 22.0 to 26.9 per cent for the fraction of total cholesterol found in alpha lipoprotein (24.4 to 26.9 per cent if one low value obtained for this serum is omitted), and from 252 to $283 \mathrm{mg}$. per cent for the total cholesterol (sum of alpha and beta fractions).

\section{DISCUSSION}

The available methods for determination of lipoprotein concentration are dependent on refractive index increment, dye binding capacity, or the content of some chemically defined material such as phospholipid or cholesterol in the lipoprotein molecule. Of these methods, the determination of cholesterol has the advantage of being based on a specific chemical reaction of a substance of known importance in atherosclerosis, while the refractive index increment is dependent on the concentration of both protein and lipids. The measurement of uptake of lipid dyes by lipoprotein fractions, which is dependent on solubility interrelationships between dye, solvent and lipid, does not appear to have as firm a basis as either of these methods (36). It should be kept in mind that lipoprotein concentrations expressed in these various units are not directly comparable because of the different composition of different normal and abnormal lipoproteins.

The wide application of some of the methods of serum lipoprotein separation and estimation has been restricted by the time, technique, amount of serum and equipment required. The estimation of alpha and beta lipoprotein cholesterol on 
eluates from electrophoretically separated serum has the advantages of being relatively simple and of requiring a minimum of serum and equipment. The time required and the number of sera which can be conveniently analyzed together are approximately the same as for the SchoenheimerSperry determination of total cholesterol, while both total cholesterol and its lipoprotein distribution are determined with the electrophoretic procedure.

\section{SUMMARY}

1. A method is described for the determination of the alpha and beta lipoprotein cholesterol of $0.02 \mathrm{ml}$. of serum separated by electrophoresis on filter paper.

2. Under the conditions described, the following criteria are satisfied:

a. A linear increase in color for increasing amounts of pure cholesterol and eluted alpha and beta lipoprotein cholesterol.

b. Agreement, within the errors of the two methods, of total cholesterol and of per cent alpha lipoprotein cholesterol as determined by the method described and by the Sperry and Webb modification of the Schoenheimer-Sperry procedure.

c. Complete recovery of eluted lipoprotein cholesterol.

d. Clear cut separation of alpha and beta lipoproteins.

e. Satisfactory reproducibility of the results in repeated determinations on the same sera.

3. Dry cholesterol on filter paper strips exposed to air at room temperature undergoes decomposition.

4. The method is comparable, in terms of time and number of sera analyzed, to the SchoenheimerSperry technique.

\section{ACKNOWLEDGMENTS}

The authors are greatly indebted to Miss Marion Hyatt for help with the Schoenheimer-Sperry cholesterol determinations, and to the Department of Biophysical Instrumentation for construction of the elution apparatus.

\section{REFERENCES}

1. Lindgren, F. T., Elliott, H. A., and Gofman, J. W., The ultracentrifugal characterization and isolation of human blood lipids and lipoproteins, with applications to the study of atherosclerosis. J. Phys. \& Colloid Chem., 1951, 55, 80.

2. Gofman, J. W., Jones, H. B., Lindgren, F. T., Lyon, T. P., Elliott, H. A., and Strisower, B., Blood lipids and human atherosclerosis. Circulation, 1950, 2, 161.

3. Lewis, L. A., and Page, I. H., Electrophoretic and ultracentrifugal analysis of serum lipoproteins of normal, nephrotic and hypersensitive persons. Circulation, 1953, 7, 707.

4. Boyle, E., Bragdon, J. H., and Brown, R. K., Role of heparin in in vitro production of alpha, lipoproteins in human plasma. Proc. Soc. Exper. Biol. \& Med., 1952, 81, 475.

5. Eder, H. A., Bragdon, J. I., and Boyle, E., The in vitro exchange of phospholipid phosphorus between lipoproteins. Circulation, 1954, 10, 603.

6. Lever, W. F., Gurd, F. R. N., Uroma, E., Brown, R. K., Barnes, B. A., Schmid, K., and Schultz, E. L., Chemical, clinical, and immunological studies on the products of human plasma fractionation. XL. Quantitative separation and determination of the protein components in small amounts of normal human plasma. J. Clin. Invest., 1951, 30, 99.

7. Cohn, E. J., Gurd, F. R. N., Surgenor, D. M., Barnes, B. A., Brown, R. K., Derouaux, G., Gillespie, J. M., Kahnt, F. W., Lever, W. F., Liu, C. H., Mittelman, D., Mouton, R. F., Schmid, K., and Uroma, E., A system for the separation of the components of human blood: Quantitative procedures for the separation of the protein components of human plasma. J. Am. Chem. Soc., 1950, 72, 465.

8. Russ, E. M., Eder, H. A., and Barr, D. P., Proteinlipid relationships in human plasma. I. In normal individuals. Am. J. Med., 1951, 11, 468.

9. Barr, D. P., Russ, E. M., and Eder, H. A., Proteinlipid relationships in human plasma. II. In atherosclerosis and related conditions. Am. J. Med., 1951, 11, 480.

10. Swahn, B., Studies on blood lipids. Scandinav. J. Clin. \& Lab. Invest., 1953, 5, suppl. 9.

11. Antonini, F. M., Piva, G., Salvini, L., and Sordi, A., Lipoprotein ed eparina nel quadro umorale della chemiopatogenesi dell aterosclerosi. Gior. di Gerontologia, 1953, suppl. 1.

12. Rosenberg, I. N., Young, E., and Proger, S., Serum lipoproteins of normal and atherosclerotic persons studied by paper electrophoresis. Am. J. Med., 1954, 16, 818.

13. Wunderly, Ch., and Piller, S., Die Färbung der im Blutserum enthaltenen Proteine, Lipoide und Kohlenhydrate nach Papier-Elektrophorese. Eine chemische Trias. Klin. Wchnschr., 1954, 32, 425. 
14. Durrum, E. L., Paul, M. H., and Smith, E. R. B., Lipid detection in paper electrophoresis. Science, 1952, 116, 428.

15. Nikkilä, E., Studies on the lipid-protein relationship in normal and pathological sera and the effect of heparin on serum lipoproteins. Scandinav. J. Clin. \& Lab. Invest., 1953, 5, suppl. 8.

16. Kunkel, H. G., and Slater, R. J., Lipoprotein patterns of serum obtained by zone electrophoresis. J. Clin. Invest., 1952, 31, 677.

17. Boyd, G. S., The estimation of serum lipoproteins. A micromethod based on zone electrophoresis and cholesterol estimations. Biochem. J., 1954, 58, 680.

18. Bolinger, R. E., Grady, H. J., and Slinker, B. J., The effect of injected heparin on the electrophoresis of the lipoproteins in patients with hypercholesterolemia. Am. J. M. Sc., 1954, 227, 193.

19. Carlson, L. A., Electrophoretic studies of serum lipoproteins. I. A description of apparatus and technique for their separation in starch medium. Acta chem. Scandinav., 1954, 8, 510.

20. Ackermann, P. G., Toro, G., and Kountz, W. B., Zone electrophoresis in the study of serum lipoproteins. J. Lab. \& Clin. Med., 1954, 44, 517.

21. Fasoli, A., Electrophoresis of serum lipoproteins on filter-paper. Acta med. Scandinav., 1953, 145, 233.

22. Kunkel, H. G., and Slater, R. J., Zone electrophoresis in a starch supporting medium. Proc. Soc. Exper. Biol. \& Med., 1952, 80, 42.

23. Zlatkis, A., Zak, B., and Boyle, A. J., A new method for the direct determination of serum cholesterol. J. Lab. \& Clin. Med., 1953, 41, 486.

24. Best, M., Van Loon, E. J., Wathem, J., and Seger, A. J., Comparison of serum cholesterol methods. Am. J. Med., 1954, 16, 601.

25. Fürst, V., Jr., and Lange, R., Evaluation of an acetic acid-sulfuric acid method for quantitative de- termination of cholesterol in serum. Scandinav. J. Clin. \& Lab. Invest., 1954, 6, 60.

26. Brice, A. T., Jr., The tryptophane content of blood serum. A new technic. J. Lab. \& Clin. Med., 1934, 19, 1113.

27. Williams, F. G., Jr., Pickels, E. G., and Durrum, E. L., Improved hanging strip paper electrophoresis technique. Science, 1955, 121, 829.

28. Sperry, W. M., and Webb, M., A revision of the Schoenheimer-Sperry method for cholesterol determination. J. Biol. Chem., 1950, 187, 97.

29. MacIntyre, I., and Ralston, M., Direct determination of serum cholesterol. Biochem. J., 1954, 56, xliii.

30. Zak, B., Dickenman, R. C., White, E. G., Burnett, H., and Cherney, P. J., Rapid estimation of free and total cholesterol. Am. J. Clin. Path., 1954, 24, 1307.

31. Sommerfelt, S. Chr., Paper electrophoresis of isolated plasma protein fractions. Scandinav. J. Clin. \& Lab. Invest., 1953, 5, 299.

32. Jencks, W. P., Jetton, M. R., and Durrum, E. L., Paper electrophoresis as a quantitative method. Serum proteins. Biochem. J., 1955, 60, 205.

33. Bergström, S., and Wintersteiner, O., Autoxidation of sterols in colloidal aqueous solution. The nature of products formed from cholesterol. J. Biol. Chem., 1941, 141, 597.

34. Oncley, J. L., and Gurd, F. R. N., The lipoproteins of human plasma in Blood Cells and Plasma Proteins. Their State in Nature, Tullis, J. L., Ed., New York, Academic Press, 1953, p. 349.

35. Technical Group, Committee on Lipoproteins and Atherosclerosis, Lipoproteins and ultracentrifugal technique. National Advisory Heart Council, 1952.

36. Jencks, W. P., and Durrum, E. L., Paper electrophoresis as a quantitative method: The staining of serum lipoproteins. J. Clin. Invest,. 1955, 34, 1437. 